\title{
Entrepreneurial Leadership of Vocational Schools Principals in Indonesia
}

\author{
Suyitno \\ Dept. of Educational Management, State University of Malang \\ J1. Semarang 5, Malang 65145, Indonesia
}

Tel: 62-341-552-888 E-mail: onteause@yahoo.com

Ahmad Sonhadji K.H.

Dept. of Technical Engineering, State University of Malang

Jl. Semarang 5, Malang 65145, Indonesia

Tel: 62-341-552-888 E-mail: asonhadjikh@yahoo.com

Imron Arifin

Dept. of Educational Administration, State University of Malang

Jl. Semarang 5, Malang 65145, Indonesia

Tel: 62-341-552-888 E-mail: ypas_malang@yahoo.com

Nurul Ulfatin

Dept. of Educational Administration, State University of Malang

Jl. Semarang 5, Malang 65145, Indonesia

Tel: 62-341-552-888 E-mail: ulfatin@yahoo.com

Doi:10.5296/ijld.v4i1.4838 URL: http://dx.doi.org/10.5296/ijld.v4i1.4838

\begin{abstract}
This study aims at describing and explaining: (1) the caharacteristics of competitive and entrepreneurial-based school; (2) the characteristics of entrepreneurial leadership exercised by school principals; (3) the strategy used by school principals in practicing entrepreneurial leadership; and (4) the relationship between school and stakeholders in strengthening the practice of entrepreneurial leadership exercised by school principals. This study uses a qualitative approach under a multiple case study design. The results of the study show that: (1) competitive and entrepreneurial-based vocational schools have certain excellence compared to other vocational schools; (2) entrepreneurial leadership exercised by school principals is characterized by the entrepreneurial values; (3) in practicing entrepreneurial leadership, school principals use some strategies, such as making some innovations related to curriculum and learning methods, guiding the students, and empowering school staff and teachers in order to create competent graduates; the school principals also help graduate students to find job and to enter labor market, and to make the school to keep in touch with these graduates; and (4) these entrepreneurial-minded school principals are able to improve and maintain good relationship between school and both internal and external stakeholders.
\end{abstract}

Key words: leadership, school principals, entrepreneurship, vocational school 


\section{Introduction}

Recently Indonesia has been facing three big problems, unemployment, poverty, and global competition. Unemployment has become a serious problem for Indonesia, especially since the economic crisis in 1997 and up to the present. The data from Badan Pusat Statistik (2012) shows that the number of labor forces in Indonesia in August 2012 reached 118 million people. The unemployment number is 7.2 million people, or $6.14 \%$. The press release from Badan Pusat Statistik (2012) also shows that in September 2012, as many as 28.59 million people $(11.66 \%)$ of the population belong to the category of poor people. Indonesia also faces the problem of increasingly fierce competition in the global world. This, among others, can be seen from the number of professional staff in Indonesia, in which foreign workers fill many job positions (Suhendra, 2012).

To solve those three problems, Indonesia should be able to strengthen the human resource through quality education. Sonhadji (2012) states that education has a major role in the development of a nation, such as the formation of the concept of nationalism, economic growth, development of science and technology, workforce preparation, and an increase in ethics and morality. Vocational education as secondary education that prepares students primarily for working on a particular field has a strategic role in preparing mid-level human resources. Research conducted by the Directorate of Vocational School concludes that there is a positive relationship between the ratio of vocational students and regional gross domestic product (GDP).

Vocational schools have moral obligation to contribute to the economic development of the country. The expectation is that these schools will become one of the solutions the country holds to tackle unemployment in line with the objectives of the schools. In Chapter 3 of the Indonesian Government Regulation No. 29 Year 1990 on Secondary Education, it is stated that the priority of vocational education is to prepare students to enter the workforce and to develop their professional attitude. The government's commitment to develop vocational education is realized by increasing the number of vocational schools since 2004 (Kompas.com, May 22, 2009). In order to realize the policy on vocational secondary schools with a ratio of 60:40 (60 for vocational schools and 40 for senior high schools) in 2020, then in 2007 the government launched the program of Vocational City. Until 2011, several cities and towns in Indonesia have been established as the vocation city or town, one of which is Malang, East Java.

Malang got the predicate as Vocational Town in 2008. This is considered an achievement, and this has led into the increasing number students entering vocational schools. The increasing number of vocational schools also brings new problems, particularly for private vocational schools, related to input, process, and output, because of the high competitive atmosphere.

The ability of some private vocational schools to survive the intense competition with public vocational schools is an interesting phenomenon. These capabilities are influenced by various factors, one of which is the principal leadership factor. Sergiovanni (1998) says that changes will have an impact on student achievement and better school performance; it is necessary to apply the entrepreneurial leadership combined with marketing principles in the management of the school to face the competition. Likewise, Tarabishy, et al. (2012) reveals that the new type of leadership that is entrepreneurial leadership is needed to be able to control the uncertain conditions in the fast pace of competition. 
Entrepreneurial leadership exercised by vocational school principals must not be seen as a mere business-oriented form, making the school and all its resources as a business company. This form of leadership is exrecised to implement the entrepreneurial spirit in the management of the school and all the educational resources. Some researchers have attempted to combine the concepts of leadership and entrepreneurship into a new leadership model, the entrepreneurial-minded leadership (entrepreneurial leadership) in order to explore leadership and entrepreneurial behavior (Gupta, et al., 2004; Tarabishy, et al., 2005). This model of leadership is needed in the conditions of competition, as Cohen (2004) states that in dynamic and complex environments as well as uncertain situation of competition, entrepreneurial leadership is needed. The leadership model is indicated to be exercised by three private vocational schools in Malang, the place where the study was conducted, namely SMK PGRI 3 Malang, SMK Muhammadiyah 2 Malang, and SMK Telkom Sandhy Putra Malang.

The three private vocational schools studied appear to have unique and different backgrounds. SMK PGRI 3 Malang focuses on discipline, SMK Muhammadiyah 2 Malang combines integrated-skills development with religious mission, and SMK Telkom Sandhy Putra puts forward abilities in the field of informatics. The uniqueness is interesting to study, especially related to the concept of entreprenurial leadership. This is because the success of SMK PGRI 3 Malang, SMK Muhammadiyah 2 Malang, and SMK Telkom Sandhy Putra Malang in maintaining their existence in a situation of intense competition can be closely associated with the principal's leadership behaviors using the insights, values, and entrepreneurial spirit in managing and leading the school.

This study focuses on four aspects: (1) the characteristics of competitive and entrepreneurial-based school; (2) the characteristics of entrepreneurial leadership exercised by school principals; (3) the strategy used by school principals in practicing entrepreneurial leadership; and (4) the relationship between school and stakeholders in strengthening the practice of entrepreneurial leadership exercised by school principals.

\section{Research Method}

This study used a qualitative approach under a multiple case study design. The method used was the constant comparative method. The study was conducted at three private vocational schools in Malang, namely SMK PGRI 3 Malang, SMK Muhammadiyah 2 Malang, and SMK Telkom Sandhy Putra Malang. The sources of data in this study were (1) informants, (2) activities and events, (3) places or location, and (4) documents. In this study, the researcher interviewed 46 informants as shown in Table 1. 
Tabel 1. Details of research informants

\begin{tabular}{|l|l|l|l|l|}
\hline No & Informants & Case I & Case II & Case III \\
\hline 1. & School Principal & 1 & 1 & 1 \\
2. & Vice Principals & - & 4 & 3 \\
3. & Department's heads & 4 & - & - \\
4. & Teachers & 3 & 2 & 3 \\
5. & Staffs & 2 & 2 & 2 \\
6. & Students & 5 & 3 & 3 \\
7. & Parents & 1 & 1 & 1 \\
8. & Alumni & 17 & 1 & 1 \\
\hline & Total & & 14 & 15 \\
\hline Notes : & Case I SMK PGRI 3 Malang & \\
& Case II $=$ SMK Muhammadiyah 2 Malang \\
Case III $=$ SMK Telkom Sandhy Putra Malang
\end{tabular}

Data was collected using three techniques, namely (1) in-depth interviews, (2) participant observation, and (3) documentation. Data analyses were done in two stages. The first was the analyses on individual cases, and the second was the cross-case analyses. To ensure validity of the data, validity checks were conducted including credibility, transferability, and confirmability.

\section{Research Results}

\subsection{The Characteristics of Competitive and Entrepreneurial-Based Vocational Schools}

Competitive private vocational school characterized by five aspects, namely: 1) an increase in the number of students; 2) $100 \%$ graduation rate, 3) ease of graduates in obtaining employment, starting self-employment, or continuing education; 4) fostering soft skills of students, and 5) good image of the school.

Each aspect is described as follows. First, an increasing number of students because of the increasing number of applicants are proportional to the availability of facilities and services, which represents the form of trust and high public interest. Second, the passing rate of $100 \%$ indicates good learning process in order to provide sufficient academic skills for students. Third, the easy of graduates in obtaining employment, self-employment, or continuing education, is due to the competence of graduates that is supported by good cooperation between schools with business or industries and universities, as well as other stakeholders. Fourth, the presence of soft skills training for students in the form of enforcement of strict discipline, teaching of religious values through habituation in the school, and attitude formation are exercised to form the readiness of the students to face the challenging world after they complete their education . Fifth, the good school image in form of comprehensive service for students since the time they start the vocational education until they graduate and get a job, they become a self-employed individual, or they attend university. In addition, the ease also comes in form of the amount of school fee as well as flexibility in the payment of the fee. The pride to be a pioneer in a particular field and ability to maintain that pioneering spirit is also the benefits students get. 
Cross-case findings on the characteristics of competitive and entrepreneurial-based vocational schools are presented on Figure 1.

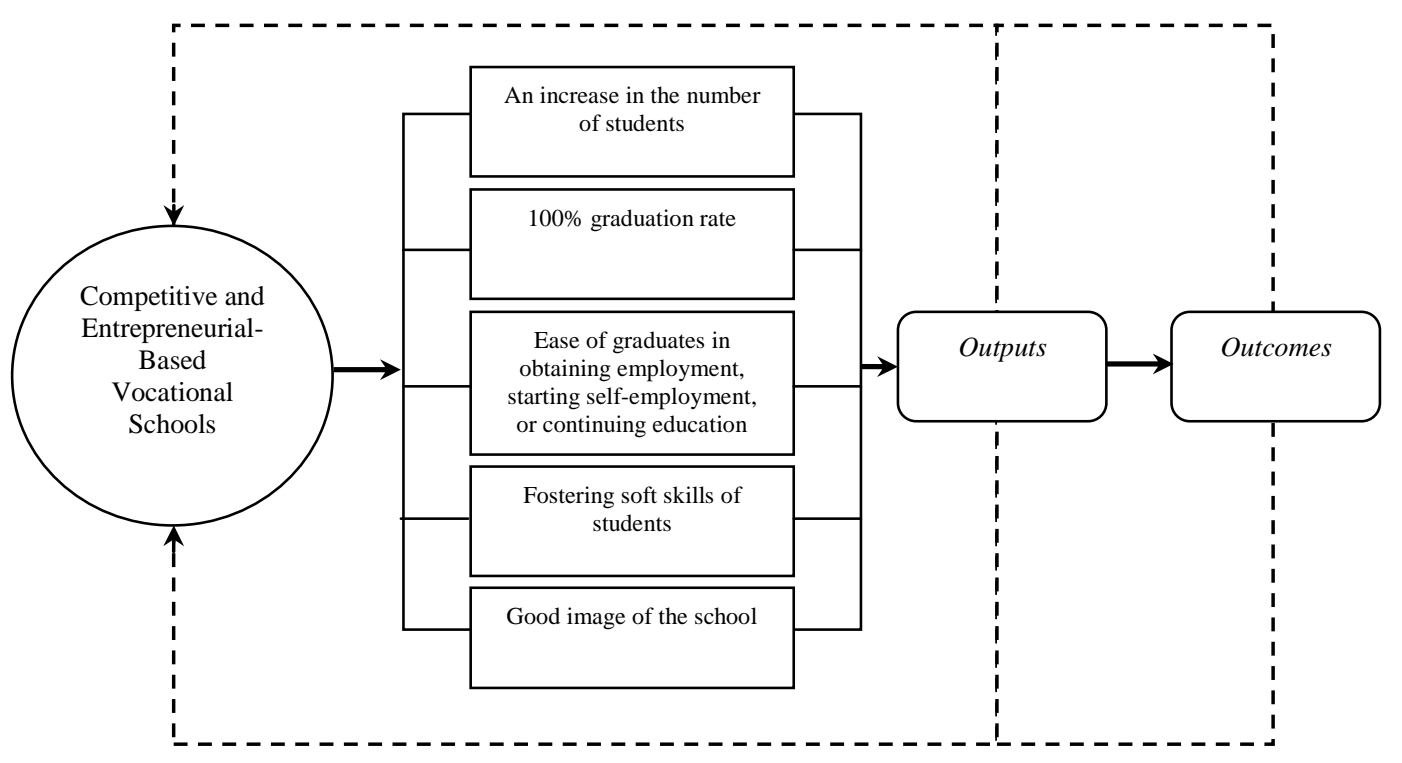

Figure 1. Characteristics of competitive and entrepreneurial-based vocational schools

\subsection{The Characteristics of Entrepreneurial Leadership Exercised by School Principals}

There are some characteristics of the entrepreneurial leaadership exercised by the school principals. First, it has a visionary perspective of the future and an advanced view, so the work done is for the progress and development of the school. Second, creative, that is having new ideas in dealing with various problems faced by the school by empowering both the resources owned and possible resources availabe for the school. Third, innovative, that is applying things that are not just new, but also different from the others as a practical application of creative ideas. Fourth, self-contained, that refers to attitudes and behaviors not easily depending on other people in completing tasks and problems of the school. Fifth, hardworking, that is seriousness in carrying out tasks and addressing problems. Sixth, risk-taking, that refers to the ability to deal with situations of uncertainty, in which possibility to fail exists, through honesty and openness. Seventh, entrepreneurial spirit, that refers to the ability to manage the resources of the school resulting in a financial gain.

Cross-case findings on the characteristics of entrepreneurial leadership exercised by school principals are presented on Figure 2. 


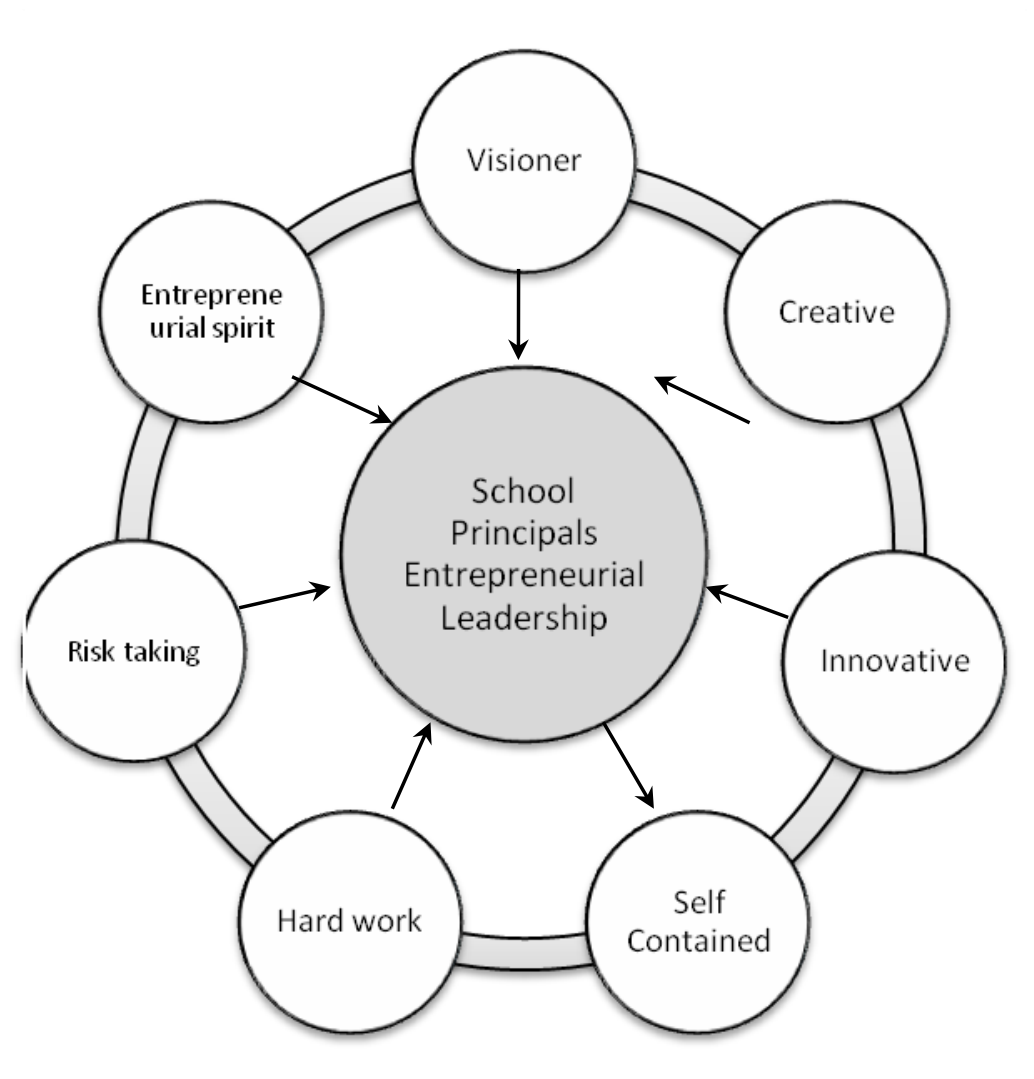

Figure 2. Characteristics of School Principals Entrepreneurial Leadership

\subsection{The Strategy Used by School Principals in Practicing Entrepreneurial Leadership}

\subsubsection{School Promotion Strategy}

School promotional purpose is generally the same, that is to improve the quantity and quality of new students, but each school has different orientation. SMK PGRI 3 Malang focuses its promotional activities to maintain branding. SMK Muhammadiyah 2 Malang focuses to educate the public and to introduce the school during promotional actvities, while SMK Telkom Sandhy Putra Malang aims at anticipating future policy changes. The orientation affects the marketing concept of each school as well. SMK PGRI 3 Malang applies "sapu bersih (clean up)" strategy, SMK Muhammadiyah 2 Malang fosters learning on Muhammadiyah concepts especially for their sister junior high schools, and SMK Telkom Sandhy Putra Malang focuses on recruiting students from other areas.

Promotion techniques used by the principals include: (1) personal communication (presentation, from person to person), (2) advertisement (internet, radio broadcasting, television broadcasting), (3) sales promotion (discount or free uang gedung), (4) publicity (events, try out sponsorship at junior high schools, etc), (5) instructional materials (brochures, guidebooks for National Final Exam success), (6) organizational design (logos, buildings, facilities, uniforms).

Acceptance of new students as a follow-up to the promotion activities is carried out in two ways, namely the regular way and special way (academic reports and transcripts, academic achievement or academic potential ability search), and independent way. 


\subsubsection{Education and Training Provision Strategy}

\subsubsection{Curriculum and Learning Materials Based on Industrial Needs}

In accordance with national policies, the core curriculum used by all three schools in the learning process is Kurikulum Tingkat Satuan Pendidikan (KTSP), synchronized with the demands of industrial world, and is adapted based on the needs of the schools. SMK PGRI 3 Malang gives greater portion to the curriculum content matching with their corporate class. SMK Muhammadiyah 2 Malang adds local content named ISMUBA (Al-Islam Kemuhammadiyahan and Arabic). SMK Telkom Sandhy Putra Malang sharpens the productive components by providing current local content competencies and by considering the needs of the information technology industry.

\subsubsection{Learning in the Production Unit}

The level of empowerment of the Production / Services Unit at the three schools varies, but the activities are directed at two aspects: giving chances for students to learn how to manage business facilities and running business units that bring financial benefits. Production / Services Unit at SMK PGRI 3 Malang has been professionally managed, so it plays roles not only as a place of learning and employment opportunities for students, but a source of income for the institution. At SMK Muhammadiyah 2 Malang, the operation of the Production / Services Unit is still within the scope of the school (internal). At SMK Telkom Sandhy Putra Malang, this kind of Production / Services Unit seems to not exist yet, since it is merely a rental facility that cannot be considered as a production unit.

3.3.2.3 Industrial Internship Programs

All the three schools studied hold industrial internship programs in certain months. The difference lies in the duration and level or semester. SMK PGRI 3 Malang holds the programs for one year in semester 3 and 4 (class XI). SMK Muhammadiyah 2 Malang implements the program for three months at the beginning of the semester 4 (class XI), while SMK Telkom Sandhy Putra Malang holds the program at the beginning of semester 5 (class XII) for three months. SMK Telkom Sandhy Putra Malang and SMK PGRI 3 Malang send more students out of town, while SMK Muhammadiyah 2 Malang holds the programs in Malang.

\subsubsection{The Implementation of Strategy for National Final Exam Success}

Regardless of the pros and cons of the National Final Examination, the schools consider this a serious matter desrving great attention and preparation. The preparation can be broadly grouped into three activities, namely (1) the addition of study time for the National Exam exercises, (2) try out, and (3) prayer / Duha prayer. These three forms of activities are designed through careful planning. All the schools have different reasons in choosing instructors for the extra hours of study. SMK PGRI 3 Malang trusts their own internal human resources (teachers) due to the reasons of ease in handling students, while SMK Muhammadiyah 2 Malang and SMK Telkom Sandhy Putra mix between their own teachers and external tutors for the sake of comparison in effectiveness. Intensity of prayers is also different. SMK Muhammadiyah 2 Malang makes the prayer a daily activity for class XII, while the other two schools hold it a few times.

\subsubsection{Character Building in Education Process}

The basic coaching for students in the three schools under study varies, but the ultimate goal is simply the same, that is character building. SMK PGRI 3 Malang imposes discipline in the process, while SMK Muhammadiyah 2 Malang focuses on moral approach. SMK Telkom Sandhy Putra Malang highlights attitude. 


\subsubsection{Development of Teachers and Staff Performance}

Private vocational schools studied have their own model in helping teachers and staff to improve productivity for the betterment of the institution. SMK PGRI 3 Malang imposes strict rules, provides rewards and punishment to teachers and staff. SMK Muhammadiyah 2 Malang tends to treat teachers and staff as a family, nurturing teachers and staff with the concept of sincerity. SMK Telkom Sandhy Putra Malang applies performance evaluation techniques, which is done not only by the superordinates, but also by the students.

\subsubsection{Graduate Marketing and Alumni Coordination Strategy}

Alumni coordination is conducted by the three schools since the students enter class XII students until they graduate. Coordination is basically done to obtain information on the effectiveness of learning materials as well as a form of school-level outcome evaluation. The media used in building up coordination among these twelfth graders are curriculum vitaes and questionnaires. When the students graduate, coordination continues using media such as shor message gateway, facebook, email, mailing lists, and direct data collection.

Graduate marketing is basically a placement activity of graduates on their desired fields, be it workplace, universities, or entrepreneur world. The private vocational schools studied do not only play role as facilitators but are also directly involved in the process of graduate marketing. This marketing can be done with specific time targets in collaboration with business or industrial world, the use of organizational networks, as well as alumni empowerment in accordance with the characteristics and capabilities of the school.

These three findings about school leadership strategies exercised by the school principlas with the entrepreneurial leadership is a cycle that is dependent each other. The linkage between the findings are illustrated in the diagram as shown in Figure 3. 


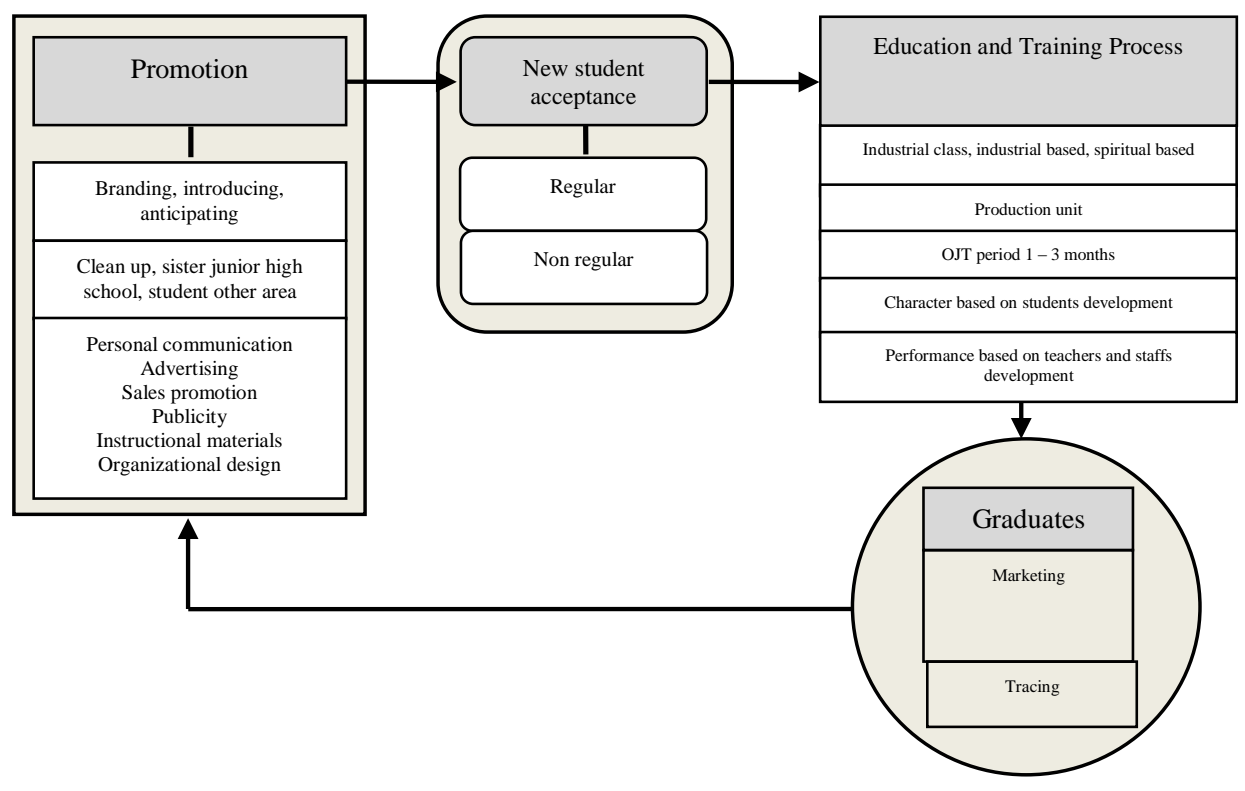

Figur 3. School Principals Entrepreneurial Leadership Strategy

\subsection{The Relationship Between School And Stakeholders in Strengthening the Practice of Entrepreneurial Leadership Exercised by School Principals}

There are 12 stakeholders strengthening the practice of entrepreneurial school leadership, each of which is as follows. The first stakeholders are teachers and school staff. Their relationship with the school is guided by the principal through formal activities in the form of meetings or informal activities in the form of the involvement of the principal in the activities of teachers and staff. This is done in order to create a conducive atmosphere that is full of intimacy, by giving space to teachers and staff to socialize. The second stakeholder is foundation, who running the school. They are especially instrumental in the foundation of formal legality, as the legal basis for the organization of private schools. The third stakeholder is the students, in which the principal through formal and personal activities builds the communication with the students. The fourth stakeholders are parents. The communication between school and parents is done through meetings, communication with parents individually related to the problems faced by the students as well as home visits. The fifth stakeholder is the board of the school in which the relationship is administratively in manners. The sixth stakeholders are alumni. The alumni play a role in the development of the school that is primarily concerned with the implementation of industrial internship programs, marketing of graduates, improvement on students' soft skills, up to the provision of infrastructure supports. The sevent stakeholders are school supervisors. The relationship with these supervisors is especially related to coaching teachers to improve the quality of their teaching. The eighth stakeholder is the industrial and business world, in which the relationship is characterized with the synchronization of curriculum, learning methods, and graduate placement, as well as coordination in term of industrial internship programs, tests on skills and competencis, and recruitment. The ninth stakeholder is the government. Schools must establish intensive communication with the government and active participation in the programs and policies made by the government. The tenth stakeholders are communities. Good relation with the surrounding community is obviously pivotal for the school activities to run well, primarily concerned with the needs of 
residential and dining facilities for students. The eleventh stakeholders are other educational institutions. Relationships with other educational institutions consist of cooperation with the junior high schools, as a supplier of prospective students, other vocational schools, and higher education. The last stakeholders are any parties that support programs related to the promotion of the schools, financing, and distribution of learning graduates.

Based on the level of involvement in school operations and its effect on the achievement of the school objectives, then the school stakeholders are divided into two groups, namely internal stakeholders and external stakeholders. These relationships are further presented in Figure 4.

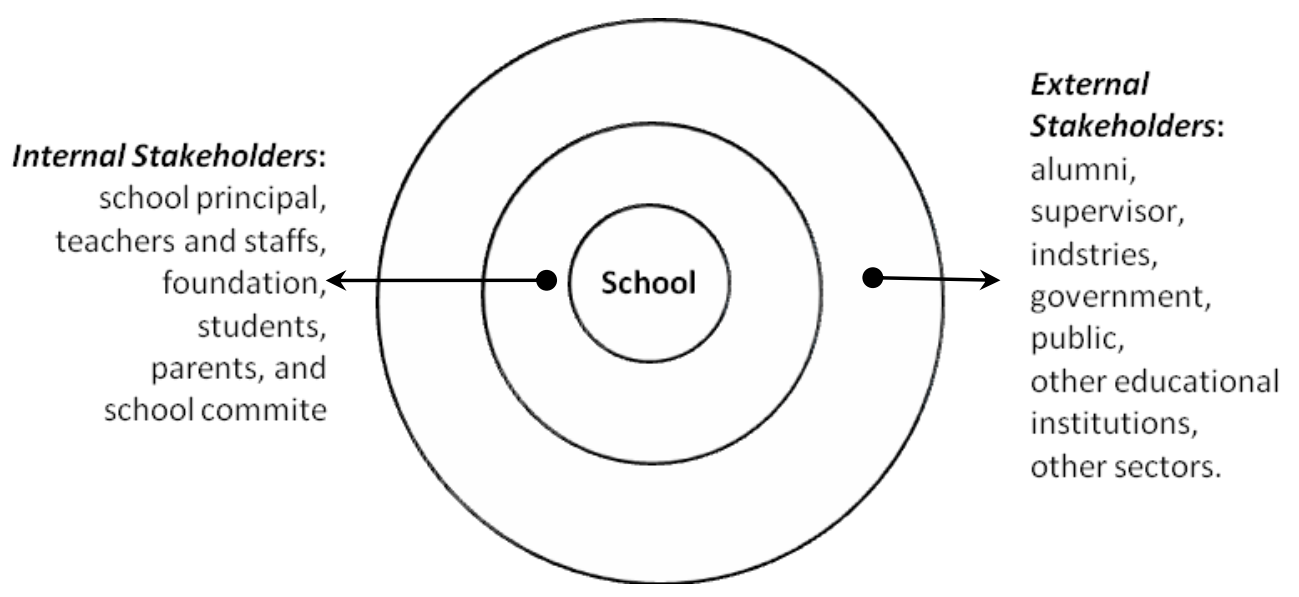

The Relationship between School And Stakeholders

Figure 4.

According to findings concerning with entrepreneurial leadership exercised by school principals illustrated in Figure 5. 


\section{Macrothink \\ Institute}

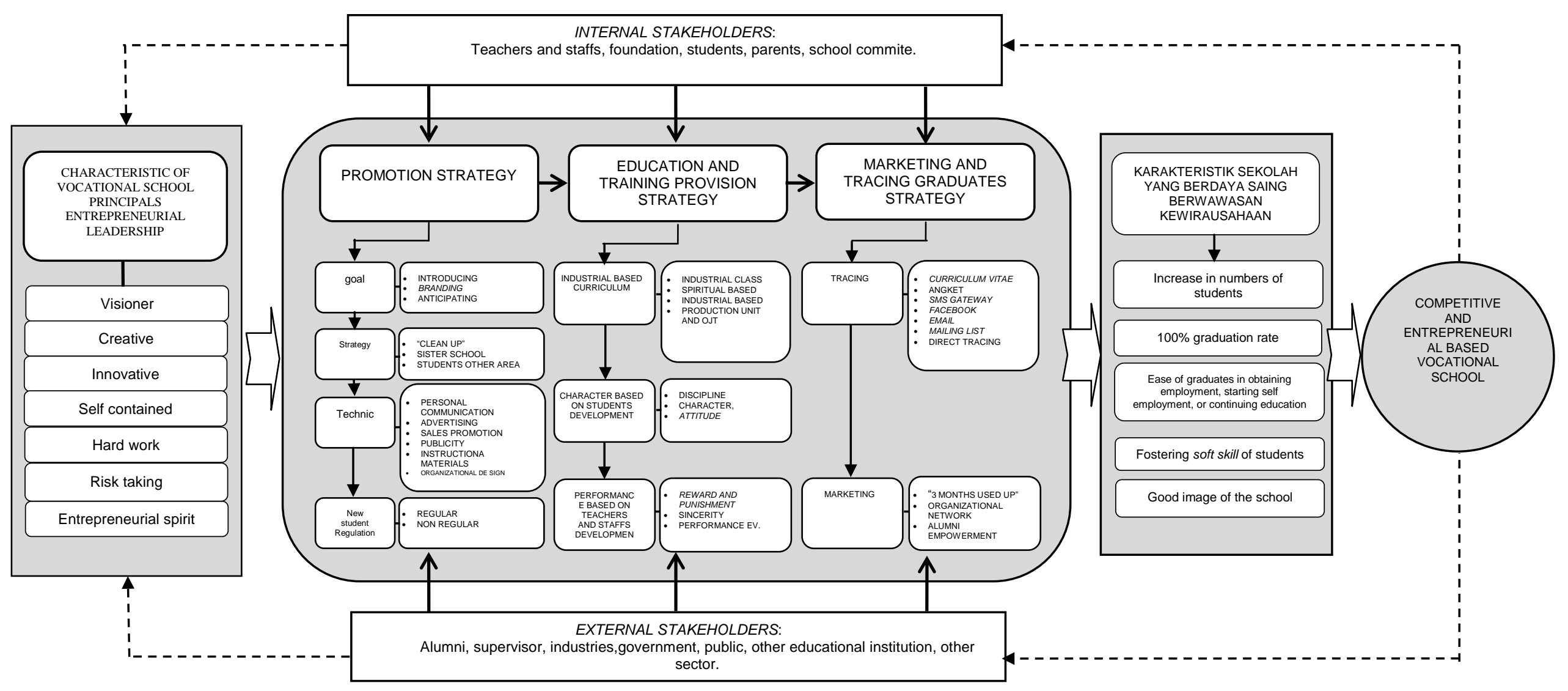

Figure 5. Model of entrepreneurial leadership practiced by vocational schools principals 


\section{Discussion}

\subsection{The Characteristics of Competitive and Entrepreneurial-Based School}

An ever-increasing number of students represent a form of higher public confidence. Djojonegoro (1998) mentions that the top schools are schools that have certain indicators including getting huge interest from the public, as can be seen from the large number of applicants, surely larger than the capacity of the school. Popularity of the schools is measured by the interest of prospective students (ratio between the numbers of accepted applicants and prospective students) (Depdikbud, 1995). Steers and Parter (1997) says that an effective organization is the one that can accomplish things beyond the other organizations doing the same things.

Graduation rate, which represents the value of academic achievement above the minimum level, is another indicator of a successful school. Beck and Murphy (1996) finds that some researchers use traditional student achievement (in the form of figures or a result-oriented approach) as one of the criteria for a successful school. It is also in accordance with the criteria of vocational success (Depdikbud, 1995) which, among others, is indicated by the ability to reach the predetermined objectives of the school; this ability is reflected through the way the school motivates learning activities and the way the students feel proud of it.

The success of vocational schools to help their graduates enter the workforce is another form of success in achieving the goal of vocational education. Oxenham (1994) states that if school graduates cannot be employed or cannot get a job matching the type and level of education they have, the school or the teachers are deemed unsuccessful with their duties. This means that the school does not to meet the needs of the community or the world of work. Educational success may also be indicated in terms of outcomes.

Discipline, religious values, and attitude, which become the values developed by the schools under study, actually represent the values of character building. These schools have implemented these values and they become the trademark that sets the schools apart from other schools. Character building is a value added for vocational graduates and an indicator of the education effectiveness. Hill (2001:5) states that the core idea of the effectiveness of schooling and school is that the school add some good values to the lives of the students, and not just the outcome alone.

According to Kotler and Armstrong (1996), a product can be seen as to have levels, and at every level, a value is added. Levels of such products include: (1) core benefit, (2) basic product, (3) the expected product, (4) argumented product, and (5) potential product. In this regard, both SMK Muhammadiyah 2 Malang and SMK PGRI 3 Malang have tried to make their education services as a potential product by adding several more values in order to satisfy students and parents. Pride on school reputation is shown by SMK Telkom Sandhy Putra Malang, in which its excellence becomes such brand-positioning. Kotler and Pfoertsch ((2008:191) state that brand-positioning deals with finding the right point in the minds of customers to create the desired association. 


\subsection{The Characteristics of Entrepreneurial Leadership Exercised By School Principals}

Studies on school leadership prove that having or being able to create a clear vision is vital for successful school leadership. (Day, 2005; Gurr, et al., 2005). Visionaries are those having a future perspective. Due to their future perspective and distant view of the future, these people will always work and act.

Entrepreneurial leaders need creative ideas. Zimmerer (1996:7) says that creative ideas often arise when entrepreuneurs look at something old and something new or think differently. Therefore, creativity is something of which no origin (generating something from nothing). According to Lumsdaine (1995:14), creativity refers to using imagination and possibilities from a variety of interactions among ideas, with other people, and with the environment to make new and meaningful connections and results. The task of a creative thinker is to cultivate ideas or elements that already exist. If the result is a combination of ideas or things previously unimaginable, but is worthy, then it will be considered as a creative thinking activity. The creative thinker will give additional value in the new combination, because the whole combination is more than just the sum of various or previous parts (Adair, 2007)

Drucker (1985) states that innovation is creating something different from the previously existing things. Educational leaders as an entrepreneur must act as an innovator who lives in a complex world of imagination and tends to make trends rather than following it. They are the developer of the organization, and have always felt uneasy with the stagnancy that occurs in the organization (Lessem, 1988). Given that creativity is also understood as capability of delivery, of developing and changing ideas, of processes, products, fashion, models, services, and certain behaviors, then innovation is the process of applying creativity factually into everyday life (Depdikbud, 2007).

Independence is closely related to self-confidence. Confidence refers to a trait that is stable, not easily tossed around by other people's opinions and suggestions. However, other people's suggestion are not rejected, but are used as a reference to consider. Indepence promotes self-confident attitude, the attitude and behavior that will lead someone to not easily depend on others to complete tasks. Being independent means that all that is being done is done based on one's own choice, is determined and decided on their own with careful consideration (Suriansyah, 2007).

Hardworking characteristic is shown through the principals' seriousness in carrying out their tasks related to the management of the school. The hardwork of the principals is not only in duration, but also in quality. The nature of the hardwork can be seen on their involvement in the work at school and their effort in finishing the work. The principals never give themselves a chance to sit down and just watch their staff doing the work; indeed, they devote full attention to the work, and is engaged in continuous employment (Sukardi, 1991). Marzuki (2013) emphasizes that people who work hard are the ones who can use their time well, any work that must be done is well practiced and professionally managed. Hardwork also means not doing useless activities or doing work lazily. 
Courage is an emotional force of a strong will to achieve a goal in the midst of challenges, both from within and from outside. The strength arises from within oneself. Courage is very important for a leader. Being leaders does not give courage to those concerned, but courage may give one a position as a leader (Maxwell , 2001). Armed with honesty and openness, people will dare to take the risk of every word they say and action they do. These leaders as well dare to do their job with a full sense of responsibility. The manifestations appears in bold attitude (not reckless or cowardly), brave, patient, and honest, as the initial for an excellent character (Soedarsono, 2009). Risk taking is also a trait that a leader must possess; that is not worried about facing an uncertain situation in which the efforts may not necessarily lead to success - but, it does not mean that a leaders does not calculate risks (Sukardi , 1991). Courage is not the absence of fear, but rather the judgment that something is more important than fear.

Entrepreneurial spirit is a trait that must be possessed by an entrepreneur (Depdikbud, 2009). Entrepreneurial competence is one of the competencies a principal must posses in accordance with the Ministerial Regulation No.13 Year 2007. One aspect of these competencies is to have an entrepreneurial spirit in managing production activities / school services a learning source for students.

\subsection{The Strategy Used by School Principals in Practicing Entrepreneurial Leadership}

The reasons to do promotional activities are given by Indradjaja and Karno (2007). Those reasons are as follows. First, we need to convince the public and customers of the education services (students, parents, and other concerned parties) that the school still holds good reputation. Second, we need to convince the public and customers of the education services (students, parents, and other concerned parties) that the education services given are relevant to their needs. Third, we need to do that kind of marketing to make the public and customers of the education services (students, parents, and other concerned parties) know and understand the educational services provided. Fourth, we need to do the marketing of educational services so that the public and customers of the education services (students, parents, and other concerned parties) do not abandon the existence of the school itself.

By adapting the opinion from Kotler and Armstrong (1996), thus the schools do some promotional strategies such as (1) advertisment (radio, television, brochures, internet, billboards), (2) presentation / sales promotion (granting discounts on education expenses, free driving courses), (3) presentation / private sales (presentation to schools), (4) public relations / publicity (exhibitions, free services, holding events, try out), and (5) person to person promotion.

Successful promotion can increase the number of applicants so selection of students can be made more rigorous. Djojonegoro (1998) mentions that execllent schools are those having certain features, one of which is the tight competition among applicants in the selection process. This is done by opening some ways in the selection of new students, namely the regular way and special way (academic reports and transcripts, academic achievement or academic potential ability search), and independent way.

Research findings related to the provision of education and training strategies include strategies for (a) curriculum and learning, (b) learning in Production Unit, (c) industrial internship programs, (d) National Final Exam success, (e) coaching students, and (f) coaching teachers and employees. 
Curriculum as an essential component in providing education and vocational training should be oriented towards the fulfillment of the above criteria. The curriculum consists of various forms, one of which is a competency-based curriculum, in which all teaching and learning activities are organized to meet the function or ability required by the labor market or the fields of work (Shoate, 1992:2). Competency-based learning pays greater attention to the relationship with the world of work rather than formal education programs (Wibowo, 2002).

Production / Service Unit refers to business activities conducted by schools continuously and professionally managed, by combining academic and business learning empowering students and school staff (Sartono in Usman, 2007). Sartono (in Usman, 2007) states that the Production / Service Unit also plays role as a business incorporated-entreprenur activity; this means that the Unit requires special authority from the school leaders. It must also be managed academically and profesionally and is formed into a formal organization belongs to the school.

The fundamental reason for industrial internship program as stated by Usman (2009: 75), "Seeing from the point of view of the ever-increasing number of unempolyment, it is urgent that educational purposes meet the needs of the world of work." The application of this approach is in the implementation of the dual system education through the link and match policy. According to Wena (1997.30), dual system education refers to the use of two learning environments, in school and out of school in the education process. Learning environments outside the school is called partner institution, referring to the business or industry, private organizations or government institutions or communities that produce goods and / or services, and other parties having the resources to help organize dual education for vocational schools.

Regardless of the pros and cons of the National Final Examination, the schools consider this a serious matter desrving great attention and preparation. The preparation can be broadly grouped into three activities, namely (1) the addition of study time for the National Exam exercises, (2) try out, and (3) prayer / Duha prayer. These three forms of activities are designed through careful planning. All the schools have different reasons in choosing instructors for the extra hours of study. SMK PGRI 3 Malang trusts their own internal human resources (teachers) due to the reasons of ease in handling students, while SMK Muhammadiyah 2 Malang and SMK Telkom Sandhy Putra mix between their own teachers and external tutors for the sake of comparison in effectiveness. Intensity of prayers is also different. SMK Muhammadiyah 2 Malang makes the prayer a daily activity for class XII, while the other two schools hold it a few times.

Various attempts are made by the schools to prepare for the National Final Examination, and these attempts are inseparable from the nature of the examination as a form of assessment. Marylin \& Quarantalory (1987:9) state that assessment is the act of determining the degree to the which an individual or group posesses a certain attribute. Thus, students' readiness and progress in learning is always measured through the try out.

Building good attitude has a significant role form changes in students' behaviors. Attitude in general is defined as the willingness of an individual to react to something (Sunarto, et al., 1999:170). Attitude underlies motives and behavior. Attitude is not an action or activity, but rather a tendency of behavior.

Building up students' characters is very important since schools, in this case the teachers, hold an important role in the formation of student behavior. According to Sunarto, et al. (1999: 
175), in an attempt to form behavior to reflecting certain life values, environmental factors play a pivotal role. Among the elements that influence the social environment, which seems to be very important, is the human beings, directly faced by the students as the embodiment of certain values. In this case, the nearest social environment, which mainly consists of those who serve as educators and coaches, are teachers. The clearer the attitude of this environment towards certain values and moral life, the more powerful the influence it brings in shaping the appropriate behavior.

Teachers and school staff need to be continually developed because they are the frontline in serving students and other stakeholders. Alma and Hurriyati (2007) confirm that all the attitudes and actions of the staff, even the way they dress and their physical appearance, have an influence on consumers' perceptions or on the success of the delivery of services.

Empowerment and coaching of teachers and staff cannot be separated from assessment. Assessment on the performance of the teaching staff in an organization refers to the process of assessing the performance of teaching staff. The purpose of the performance assessment in general is to provide feedback to the staff in order to improve and increase the productivity of the organization.

Alumni coordination conducted by the schools start since the students are in grade XII until they graduate. Coordination is basically done to obtain information on the effectiveness of learning materials as well as a form of school-level outcome evaluation. The media used in building up coordination among these twelfh graders are curriculum vitaes and questionnaires. When the students graduate, coordination continues using media such as shor message gateway, facebook, email, mailing lists, and direct data collection. Wuradji, et al. (2010) states that one of the important benefits of this kind of coordination is to obtain information about the relevance of educational programs with the needs of the field of work. Finch, et al. (in Wuradji, et al., 2010) argues that this coordination aims to determine the mobility and job satisfaction of graduates. Meyer, et al. (in Wuradji, et al., 2010) classify the search and coordinationpurpose into three categories, namely (a) to improve teaching and learning at schools; (b) to assist graduates in finding employment; and (c)to gather important information that can be used to improve the program .

Graduate marketing is basically a placement activity of graduates on their desired fields, be it workplace, universities, or entrepreneur world. The private vocational schools studied do not only play role as facilitators but are also directly involved in the process of graduate marketing. This is in line with the goal of marketing as stated by Kotler and Fox (1995), in which specific markteing exercised by schools is actually a process of analysing, planning, implementing, and controlling, which is formulated and designed carefully for the good of the schools, the graduates, and the workforce.

\subsection{The Relationship Between School and Stakeholders in Strengthening the Practice of Entrepreneurial Leadership Exercised by School Principals}

By fostering good relationships with teachers and school staff, it is expected that the desire to provide best services and become the best school can be developed and maintained. Good cooperation with teachers and school staff is very important as Bliss (1991) states that the school can be effective if the head of the school is able to create an atmosphere of order, disciplined, and purposefull; an atmosphere full of expectations for the staff and students; good 
cooperation among the staff; good commitment to achieve goals; sufficient time to provide guidance and to develop the staff.

The organization founding the school has a major role in the aspect of legality. The three schools admit their association with the organizations the schools belong to, but the direct involvement of each organization in the operation of the schools is different. The role can be either administrative and formal, full authority for the school management, or direct involvement.

There are two approaches used in the management of learners (Yeager, 1994). First, the quantitative approach that focuses more on aspects of administrative and bureaucratic institutions. Second, the qualitative approach that pays more attention to the welfare of the students.

Involving parents in the education of children at schools is based on the view that family plays important roles in shaping the cultural attitudes of children. Thus, school needs to work closely with the family, so that both parties can have same perceptions, attitudes, and actions in the process of preparing students to face the challenges of the future (Suriansyah, 2007).

Based on the Decree of the Minister of National Education No. 044/U/2002 on the Board of Education and the School Committee, the School Committee should act as: (1) an advisory agency by providing suggestions in the determination and implementation of education policy in the education unit, (2) a supporting agency, to support either in the form of financial, thoughts, and efforts in the provision of education in the education unit, (3) a controlling agency, to control activities and spending in the education unit within the framework of transparency and accountability, and (4) to mediate relationship between the government (executive) with the community and the education unit.

The relationship between the alumni of the school is very good and is beneficial for the development of schools, especially in the placement of students for industrial internship program and graduate marketing.

The school superintendents have a significant and strategic role in the process and results of quality education in schools. In this context, the role of the school superintendents include monitoring, supervision, evaluation, reporting, and follow-up that should be done regularly and continuously (Government Regulation No. 19 of 2005, section 55). The role relates to the duties of supervisors in managerial and academic supervision, as well as coaching, monitoring, and assessment.

Cooperation with industries is the realization of the policy "link and match". This relationship is crucial in order to improve the quality of vocational education as to make it in line with the needs of the workforce. This can be achieved through a variety of activities, for example in the selection of new students, planning for school programs, industrial internship programs, competency testing, teacher internships, and co-operation in industrial production units through teaching at schools (Depdikbud, 1995)

Private vocational schools are structurally belong to the founding organization; yet, they cannot be separated from the government as a regulator in the field of education. This is mainly related to external and macro policies and school development programs, including government assistance, both for physical and management development. Local governments 
play more dominant roles than the provincial governments and the central government. The local government functions in the areas of facilitating education and regulating cooperation among educational institutions in the region. The local government also controls the output of educational institutions in the region in order to improve the quality of human resources (Tilaar, 2002)

In Article 54 of Law Number 20 Year 2003 on National Education System, it is stated that community participation in education includes the participation of individuals, groups, families, professional organizations, employers, and community organizations in organizing and controlling the quality of education services. With the onset of intensive contacts between schools and community, it is expected that this relationship can function optimally. Educational institutions substantially have multiple roles for the community: to provide services and as an agent of change, which is named as the service function and leadership function (functions to advance the community through the establishment of quality human resources) by Stoops (1981).

Relationships with other educational institutions are built up not only with the same level (senior high school), but also with different levels and even different paths. The relationship is based on the mutual cooperation, namely: (1) cooperation with junior high schools in order to get quality input (graduates of good junior high schools). Form of connection in the form of promotional activities, and development ; (2) cooperation with other vocational schools in order to share matters concerning school development through MKSS for principals and MGMD for teachers; (3) cooperation with universities for improvement of quality management and human resources as well as the distribution of school graduates who continue their studies to higher education. This cooperation takes the form of guest lecturers, college scholarships, student research, internships, and many others. School also cooperates with non-formal education institutions, such as tutoring agencies in order to improve the ability of students in a particular field, especially to prepare for the National Final Exam.

School relationships with other parties related to school operations are done with the aims of, among others, the completion of the academic and non-academic problems, school promotion, financial assistance for both students and institutions, improvement on the quality of learning, as well as the distribution of graduates. The relationship can also be hierarchical as it is between PT. Telkom Tbk with SMK Telkom Sandhy Putra Malang.

\section{Conclusion}

In line with the objectives of this study, the researchers formulate some conclusions as follows. First, competitive private vocational schools is characterized by their ability to achieve more than other private vocational schools. The achievement can be seen from their excellences in terms of: (1) an increase in the number of students, (2) ability to maintain a passing rate of 100 $\%$, (3) ease of graduates in obtaining employment, in regulating self-employment, or in continuing education, (4) the presence of soft skills training for students, and (5) the ability to maintain and enhance the image of the school as a good and reputable school. Second, principals whose leadership is based on the values of entrepreneurial leadership hold these values in the management of the school: (1) visionary, (2) creative, (3) innovative, (4) independent, (5) hardworking, (6) risk-taking, and (7) entrepreneurial spirit. Third, there are some strategies applied by these school principals in the management of the school based on the entrepreneurial leadership method. Those strategies are (1) school promotion strategy to maintain branding, introduce school, and anticipate changes in government policy, (2) 
education and training strategy, which consists of strategies related to curriculum and learning materials, such as enterprise, religious content (Kemuhammadi-yahan) and field-based competency (IT); learning in Production Unit; industrial internship programs; National Exam success strategy; strategy in building up students' characters (disciplined, morality, and attitude); coaching teachers based on reward and punishment, sincerity, and performance assessment, and (3) graduate marketing and alumni coordination strategy conducted since the students are in class XII through the collection of students' biodata, curriculum vitaes, and questionnaires, and continued until the students graduates through short message gateway, facebook, email, mailing lists, and direct data collection. Graduate marketings is performed with a target time (expired in 3 months) by leveraging relationships with industrial and business world, empowering organizational networks (Muhammadiyah), as well as the empowerment of alumni. Fourth, school relationship with stakeholders in strengthening entrepreneurial school leadership practices includes internal stakeholders and external stakeholders.

\section{References}

Adair, J. (2007). The Art of Creative Thinking. London: Kogan Page.

Alma, B. dan Hurriyati, R. (2007). Manajemen Corporate dan Strategi Pemasaran Jasa Pendidikan Fokus pada Mutu dan Layanan Prima. Bandung: CV. Alfabeta.

Beck, L.G. dan Murphy, J. (1996). The Four Imperatives of Successful School. Thousands Oaks, California: Corwin Press, Inc.

Bliss, J.R. (1991). Strategic and Holistic Images of Effective Schools. J.R. Bliss, W.A. Firestone \& C.E. Richards (eds). Rethinking Effective Schools: Research and Practice (pp. 43-57). Englewood Cliffs, New Jersey: Prentice Hall.

Cohen, A. R. (2004). Building a company of leaders. Leader to Leader, (34):16-20.

Day, C. (2005). Sustaining Success in Challneging Contexts: Leadership in English Schools. Journal of Educational Administration. 43 (6).

Depdikbud. (1995). Indikator Keberhasilan Sekolah Menengah Kejuruan. Jakarta: Direktorat Pendidikan Menengah Kejuruan, Direktorat Pendidikan Dasar dan Menengah - Depdikbud.

Djojonegoro, W.(1998). Lima Tahun Mengemban Tugas Pengembangan SDM: Tantangan yang Tiada Hentinya. Jakarta: Balitbang, Depdikbud.

Fernald L,W., Jr. dan Solomon, G.T. (1996). Entrepreneurial leadership: Oxymoron or new paradigm. The Journal of Management Systems. 8: 2-16.

Gupta, V., MacMillan, I.C dan Surie, G. (2004). Entrepreneurial leadership: Developing and measuring a cross-cultural construct. Journal of Business Venturing 19(2): 241-60.

Gurr, D., Drysdale, L., dan Muford, B. (2005). Succesfull Principal Leadership: Australian Case Studies. Journal of Educational Administration. 43 (6).

Hisrich, R.D. dan Peters, M.D. (1992). Entrepreneurship, Starting,Developing, nd Managing A New Entreprise. New York, Richcard D. Irwin, Inc.

Kotler, P. dan Amstrong, G. (1996). Principles of Marketing (6 ${ }^{\text {th }}$ Edition). New Jersey: Prentice Hall.

Kotler, P. dan Fox, KFA. (1995). Strategic Marketing for Educational Institution. Englewood Cliffs, New Jersey: Prentice Hall. 
Kotler, P. dan Pfoertsch, W. (2008). B2B Brand Management. Jakarta: PT. Bhuana Ilmu Populer Kelompok Gramedia.

Lessem, R. (1988). Intrapreneurship: How to be an enterprising individual in a successfull business. England: Gower Publishing Company.

Lippitt, G.L. 1987. Entrepreneurial leadership: A performing art. The Journal of Creative Behaivor. 21 (3): 264-270.

Lumsdaine, E. dan Monika. (1995). Creative Problem Solving: Thinking Skills for a Changing World. New York: McGraw-Hill Internasional Editions

Marylin, K dan Quarantalory.(1987). Effective Teaching Principles and Practice. London: Scott.

Maxwell, J.C. (2001). The 21 Indispensable Qualities of a Leader (21 Kualitas Kepemimpinan Sejati). Terjemahan Arvin Saputra. 2001. Jakarta: Interaksa.

Porter, M.E. (1980). Competitive Strategy. New York: Free Press

Sergiovanni, T.J. (1998). Leadership as pedagogy, capital development and school effectiveness. International Journal of Leadership in Education. 1 (1): 37-46.

Shoate, J.S. (1992). Curriculum Based Assessment and Programming. Boston: Allyn and Bacon, Inc.

Skogen, K. (2010). Entrepreneurial Leadership -Towards a Better School. Dalam K. Skogen dan J. Sjøvoll (Eds). Creativity and Innovation - Preconditions for entrepreneurial education. Trondheim: Tapir Academic Press

Sonhadji, A. (2012). Manusia, Teknologi, dan Pendidikan Menuju Peradaban Baru. Malang: Penerbit Universitas Negeri Malang (UM Press).

Steers, R.M dan Porter, L. W.(2001). Motivation and Work Behavior. New York: Accademic Press

Stoops, E., Rafferty, M., dan Johnson, R.E. (1981). Handbook of Educational Administration, A Guide for The Practitioner (Second Edition). Boston: Allyn and Bacon, Inc.

Tarabishy, A, Fernald, L.W., Solomon, G.T. Understanding Entrepreneurial Leadership in today's Dynamic Markets. www.sbaer.uca.edu/ research/ usasbe/2003/pdffiles/papers/21.pdf. (January 18, 2012).

Tarabishy, A., Solomon, G.T, Fernald, Jr. L.W, dan Sashkin, M. (2005). The entrepreneurial leader's impact on the organization's performance in dynamic markets. Journal of Private Equity 8(4): 20-29.

Zimmerer, T.W. (1996). Entrepreneurship and The New Venture Formation. New Jersey: Prentice Hall Inc. 